\title{
Electron paramagnetic resonance of manganese-doped strontium titanate
}

\section{(Ressonância paramagnética eletrônica de titanato de estrôncio dopado com manganês)}

\author{
R.S. de Biasi ${ }^{1 *}$, M.L. N. Grillo ${ }^{2}$ \\ ${ }^{1}$ Instituto Militar de Engenharia, Seção de Engenharia de Materiais, 22290-270, Rio de Janeiro, RJ, Brazil \\ ${ }^{2}$ Universidade do Estado do Rio de Janeiro, Instituto de Física, 20550-013, Rio de Janeiro, RJ, Brazil
}

\begin{abstract}
Electron paramagnetic resonance (EPR) spectra of manganese-doped strontium titanate were investigated for several Mn concentrations. The spectra of $\mathrm{Mn}^{2+}$ and $\mathrm{Mn}^{4+}$ ions were observed and attributed, respectively, to $\mathrm{Mn}$ ions occupying $\mathrm{Sr}^{2+}$ and $\mathrm{Ti}^{4+}$ sites. The relative intensity of the spectra suggested that the manganese ions occupy preferentially $\mathrm{Ti}^{4+}$ sites. The results showed that the EPR peak-to-peak linewidth of the $\mathrm{Mn}^{4+}$ spectrum increases with manganese concentration according to the theoretical equation $\Delta \mathrm{H}_{\mathrm{pp}}=0.45+210$.f. $(1-\mathrm{f})^{80}(\mathrm{mT})$. This suggested that the exchange interaction between tetravalent manganese ions in strontium titanate has an approximate range of $0.96 \mathrm{~nm}$, comparable to that of $\mathrm{Gd}^{3+}$ in the same compound.
\end{abstract}

Keywords: ceramics, electron paramagnetic resonance, strontium titanate, manganese.

Resumo

Espectros de ressonância paramagnética eletrônica de titanato de estrôncio dopado com manganês foram investigados para várias concentrações de Mn. Os espectros dos íons de $\mathrm{Mn}^{2+}$ e $\mathrm{Mn}^{4+}$ foram observados e atribuídos, respectivamente, a íons de Mn ocupando sítios do $\mathrm{Sr}^{2+}$ e do $\mathrm{Ti}^{4+}$. A intensidade relativa dos dois espectros sugeriu que os íons de manganês ocupam preferencialmente os sítios do $\mathrm{Ti}^{4+}$. Os resultados mostraram que a largura de linha pico a pico do espectro do $\mathrm{Mn}^{4+}$ aumenta com a concentração de manganês de acordo com a equação teórica $\Delta H_{p p}=0,45+210 . f .(1-f)^{80}(m T)$. Isto sugeriu que a interação de câmbio entre íons de manganês tetravalente tem um alcance aproximado de $0,96 \mathrm{~nm}$, comparável ao do $\mathrm{Gd}^{3+}$ no mesmo composto.

Palavras-chave: cerâmicas, ressonância paramagnética eletrônica, titanato de estrôncio, manganês.

\section{INTRODUCTION}

Strontium titanate $\left(\mathrm{SrTiO}_{3}\right)$ is a ceramic material with several industrial applications [1-5] whose properties can be improved by doping [6-10]. In this work, we investigate the influence of the degree of Mn doping on the electron paramagnetic resonance (EPR) linewidth of $\mathrm{Mn}^{4+}$ in polycrystalline $\mathrm{SrTiO}_{3}$. In this way, one can use the EPR results to measure, rapidly and nondestructively, small concentrations of $\mathrm{Mn}$ in commercial $\mathrm{SrTiO}_{3}$, as it has been done for other ions and other ceramic materials [1116]. In addition, the extent of the interaction of tetravalent manganese ions in manganese-doped strontium titanate may be helpful for the investigation of the magnetic behavior of manganese-doped barium titanate, which could be used as a multiferroic material, since, in these materials, magnetic and electric properties coexist and manganese is a dopant with a strong influence on both electric and magnetic properties $[9,10,17]$. A previous investigation by EPR of manganesedoped strontium titanate [17] has shown that Mn ions may occupy either $\mathrm{Sr}^{2+}$ sites or $\mathrm{Ti}^{4+}$ sites. The $\mathrm{Mn}^{2+}$ spectrum is

*rsbiasi@ime.eb.br

Dhttps://orcid.org/0000-0001-8897-5969 described by a spin Hamiltonian with parameters $\mathrm{g}=2.0032$ and $\mathrm{A}=82.8 \times 10^{-4} \mathrm{~cm}^{-1}$, while the $\mathrm{Mn}^{4+}$ spectrum is described by a spin Hamiltonian with parameters $\mathrm{g}=1.9920$ and $\mathrm{A}=71.2 \times 10^{-4} \mathrm{~cm}^{-1}$.

EPR of paramagnetic impurities in solids: according to previous works $[18,19]$, the peak-to-peak first derivative linewidth is given by:

$$
\Delta \mathrm{H}_{\mathrm{pp}}=\Delta \mathrm{H}_{\mathrm{o}}+\Delta \mathrm{H}_{\mathrm{d}}=\Delta \mathrm{H}_{\mathrm{o}}+\mathrm{c} . \mathrm{f}_{\mathrm{e}}
$$

where $\Delta \mathrm{H}_{\mathrm{o}}$ is the intrinsic linewidth, $\Delta \mathrm{H}_{\mathrm{d}}$ is the dipolar broadening, $\mathrm{c}$ is a constant, and $\mathrm{f}_{\mathrm{e}}$ is the concentration of substitutional ions of the paramagnetic impurity not coupled by the exchange interaction, which can be expressed as:

$$
f_{e}=f .(1-f)^{z\left(r_{c}\right)}
$$

where $f$ is the impurity concentration, $z\left(r_{c}\right)$ the number of cation sites included in a sphere of radius $r_{c}$, and $r_{c}$ the effective range of the exchange interaction.

\section{EXPERIMENTAL PROCEDURE}

Sample preparation: the sample preparation method 
was the same as in [20]. The starting materials were reagent grade $\mathrm{SrTiO}_{3}$ (Aldrich, $<5 \mu \mathrm{m}, 99 \%$ ) and $\mathrm{MnO}_{2}$ (Carlo Erba, $99 \%$ ). The powders of $\mathrm{SrTiO}_{3}$ and 0.1 to $3.0 \mathrm{~mol} \%$ of $\mathrm{MnO}_{2}$ were ground together, and then the mixtures were fired for $24 \mathrm{~h}$ at $1200{ }^{\circ} \mathrm{C}$ in air.

Measurements: X-ray diffraction measurements were performed in a Panalytical X'Pert Pro diffractometer with $\mathrm{CuK} \alpha$ radiation $(0.154 \mathrm{~nm})$. All magnetic resonance measurements were performed at room temperature and $9.50 \mathrm{GHz}$ using an electron paramagnetic resonance (EPR) spectrometer (Varian, E-12) with $100 \mathrm{kHz}$ field modulation. The microwave power was $200 \mathrm{~mW}$, and the modulation amplitude was $0.1 \mathrm{mT}$. The magnetic field was calibrated with an NMR gaussmeter.

\section{EXPERIMENTAL RESULTS}

$X$-ray diffraction: all diffractograms (a typical one is shown in Fig. 1) were indistinguishable from the diffractogram of pure $\mathrm{SrTiO}_{3}$ (JCPDS 86-0179). This was expected, since the Mn doping, up to only $3.00 \mathrm{~mol} \%$, was not enough to change either the lattice constant or the amplitude of the diffraction peaks as long as the Mn ions remained in solid solution, as attested by the fact that no other lines than those attributed to $\mathrm{SrTiO}_{3}$ were observed. Moreover, the lines were very narrow, as expected from micron-sized particles.

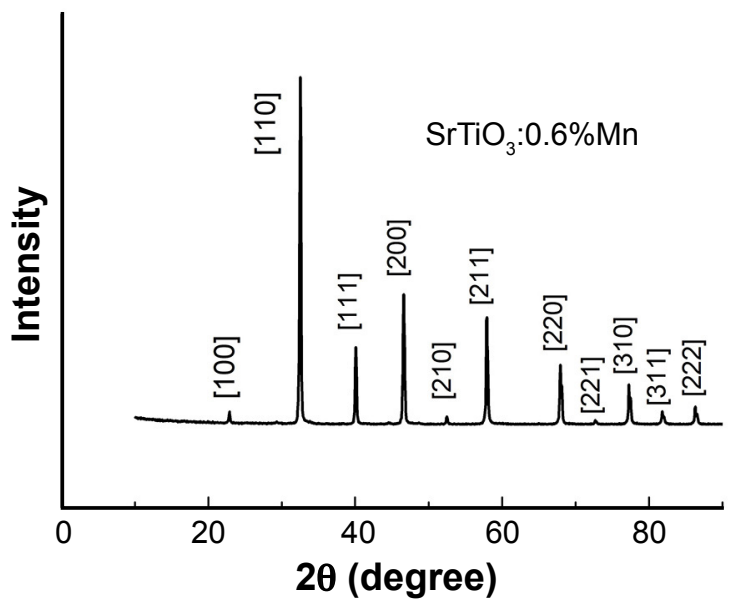

Figure 1: X-ray diffraction pattern of a $\mathrm{SrTiO}_{3}$ sample doped with $0.6 \mathrm{~mol} \% \mathrm{Mn}$. The indices were taken from the file JCPDS 86-0179.

[Figura 1: Difratograma de raios $\mathrm{X}$ de uma amostra de $\mathrm{SrTiO}_{3}$ dopada com 0,6 mol\% de Mn. Os índices foram obtidos do arquivo JCPDS 86-0179.]

EPR spectra: the spectrum of a typical sample is displayed in Fig. 2. Two sextets were seen, one with $g=2.00$ and another with $\mathrm{g}=1.99$. Due to the similarity of the measured g-values and hyperfine constants to those of previously reported spectra [14], the first sextet was attributed to $\mathrm{Mn}^{2+}$ ions occupying $\mathrm{Sr}^{2+}$ sites and the second to $\mathrm{Mn}^{4+}$ ions occupying $\mathrm{Ti}^{4+}$ sites. The intensity of the second sextet was much larger than that of the first for all concentrations and increased with Mn concentration, while the intensity of the first sextet remained the same and was thus discarded from our calculations. On the other hand, the data showed that the intensity of a broad line that was seen in all spectra and was attributed to Mn-rich clusters [21, 22] increased at the same rate as the spectrum of $\mathrm{Mn}^{4+}$ ions. Even if a significant fraction of the doping $\mathrm{Mn}$ is incorporated to $\mathrm{Mn}$ rich clusters, this does not invalidate our analysis, as long as the intensity of this line increases at the same rate as the intensity of the $\mathrm{Mn}^{4+}$ spectrum with $\mathrm{Mn}$ concentration, since this lack of correspondence between the nominal doping and the effective concentration of $\mathrm{Mn}$ in $\mathrm{Mn}^{4+}$ sites leads only to a small decrease in the value of $\mathrm{c}$ in Eq. A, but does not affect the concentration dependence of the linewidth of the $\mathrm{Mn}^{4+}$ ions. The linewidths of the hyperfine lines of the sextet with $g=1.99$ appear in Table I for several manganese concentrations. We concentrated our attention on the line pointed out by an arrow in Fig. 3 because it is the one with less superposition with the lines of the other sextet.

\section{DISCUSSION}

In the discussion that follows, the contribution of $\mathrm{Mn}^{2+}$ in $\mathrm{Sr}^{2+}$ sites is ignored, since, according to intensity data, the fraction of ions in these sites was negligibly small. The theoretical functions for $\Delta \mathrm{H}_{\mathrm{pp}}$, given by Eq. A, are shown in Fig. 4 for $\Delta \mathrm{H}_{0}=0.45 \mathrm{mT}$ and 8 different values of $r_{c}$, computed from the lattice constant of $\mathrm{SrTiO}_{3}$ [17], $a_{0}=0.3901 \mathrm{~nm}$. The values of $z\left(r_{c}\right)$, given in Table II for $\mathrm{n}=1$ to 8 , are those consistent with the crystal lattice of $\mathrm{SrTiO}_{3}$. The experimental results, also displayed in Fig. 2, followed closely the theoretical function for $n=7$, given by Eq. C, which, as can be seen in Table II, corresponded to $\mathrm{r}_{\mathrm{c}}=0.96 \mathrm{~nm}$.

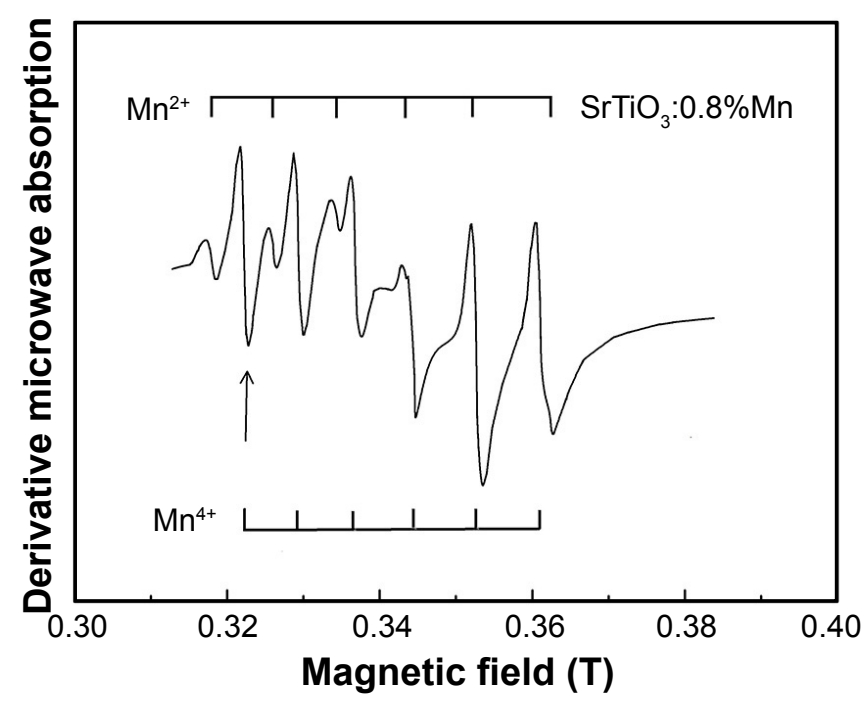

Figure 2: EPR spectrum of an $\mathrm{SrTiO}_{3}$ sample doped with $0.8 \mathrm{~mol} \% \mathrm{Mn}$. [Figura 2: Espectro de RSE de uma amostra de $\mathrm{SrTiO}_{3}$ dopada com $0,8 \mathrm{~mol} \% \mathrm{Mn}$.] 
Table I - Experimental results for the $\mathrm{Mn}^{4+}$ peak-to-peak linewidth in $\mathrm{SrTiO}_{3}(\mathrm{~T}=300 \mathrm{~K}, v=9.50 \mathrm{GHz})$. [Tabela I - Resultados experimentais para a largura de linha pico a pico de $\mathrm{Mn}^{4+}$ em $\mathrm{SrTiO}_{3}(\mathrm{~T}=300 \mathrm{~K}, v=9,50 \mathrm{GHz})$.]

\begin{tabular}{ccccccccccc}
\hline $\mathrm{f}(\mathrm{mol} \%)$ & 0.10 & 0.20 & 0.40 & 0.60 & 0.80 & 1.00 & 1.50 & 2.00 & 2.50 & 3.00 \\
\hline$\Delta \mathrm{H}_{\mathrm{pp}}(\mathrm{mT})$ & 0.63 & 0.84 & 1.10 & 1.20 & 1.30 & 1.40 & 1.35 & 1.24 & 1.24 & 1.06 \\
\hline
\end{tabular}

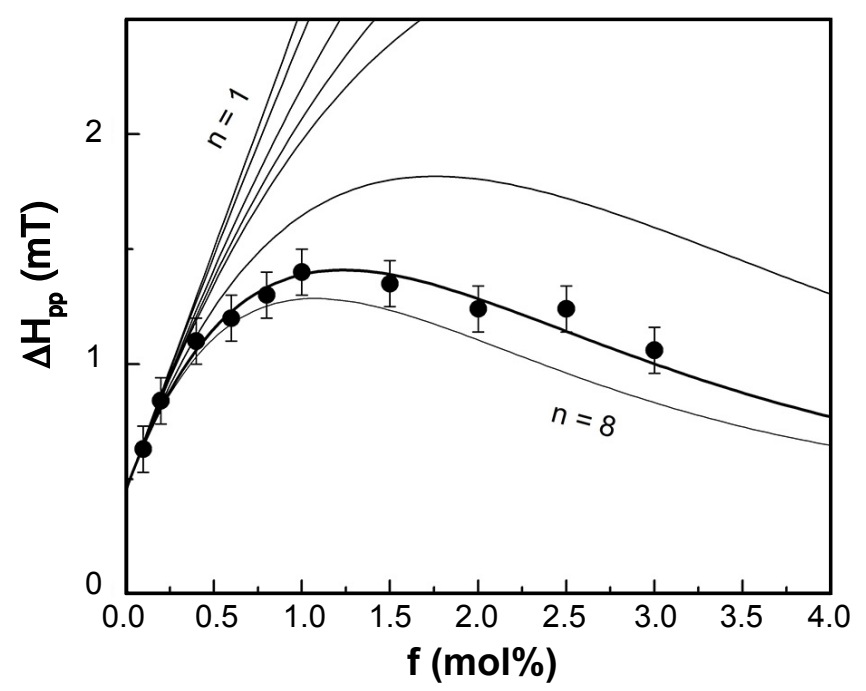

Figure 3: Concentration dependence of the peak-to-peak linewidth, $\Delta \mathrm{H}_{\mathrm{pp}}$, in $\mathrm{Mn}$-doped $\mathrm{SrTiO}_{3}$. The circles are experimental points; the curves represent the results of theoretical calculations for 8 different ranges of the exchange interaction.

[Figura 3: Variação da largura de linha pico a pico, $\Delta H_{p p}$, com a concentração em amostras de $\mathrm{SrTiO}_{3}$ dopadas com $\mathrm{Mn}$. Os círculos são pontos experimentais; as curvas mostram o resultado de cálculos teóricos para 8 alcances diferentes da interação de câmbio.]

$$
\Delta \mathrm{H}_{\mathrm{pp}}=0.45+210 . \mathrm{f} \cdot(1-\mathrm{f})^{80}
$$

The peak-to-peak linewidth of $\mathrm{Mn}^{2+}$ in $\mathrm{SrTiO}_{3}$ is compared in Fig. 4 with that of $\mathrm{Gd}^{3+}$ in the same host lattice, which can be approximated by the equation $\Delta \mathrm{H}_{\mathrm{pp}}=0.60+600$.f.(1-f) ${ }^{80}(\mathrm{mT})$ [18]. Although $\mathrm{r}_{\mathrm{c}}$ is the same for both ions, the value of $\mathrm{c}$ in Eq. A is much larger for $\mathrm{Gd}^{3+}$, i.e., the linewidth rises much faster with the $\mathrm{Gd}^{3+}$ concentration than with the $\mathrm{Mn}^{4+}$ concentration. A probable explanation is that, according to Table III, the difference in ionic radii is much higher between $\mathrm{Sr}^{2+}$ and $\mathrm{Gd}^{3+}$ than between $\mathrm{Ti}^{4+}$ and $\mathrm{Mn}^{4+}$, since, as discussed in [24], the coefficient $\mathrm{c}$ in Eq. A increases with the difference $\Delta \mathrm{r}$ between the ions of the dopant and the replaced element. Moreover, as previously discussed, the presence of a broad line showed that not all Mn ions
Table III - Ionic radii [23] and their differences. [Tabela III - Raios iônicos [23] e suas diferenças.]

\begin{tabular}{cccc}
\hline Ion & Coordination & Radius (nm) & Difference (nm) \\
\hline $\mathrm{Sr}^{2+}$ & 12 & 0.144 & 0.044 \\
$\mathrm{Gd}^{3+}$ & 12 & 0.100 & \\
$\mathrm{Ti}^{4+}$ & 6 & 0.061 & 0.008 \\
$\mathrm{Mn}^{4+}$ & 6 & 0.053 & \\
\hline
\end{tabular}

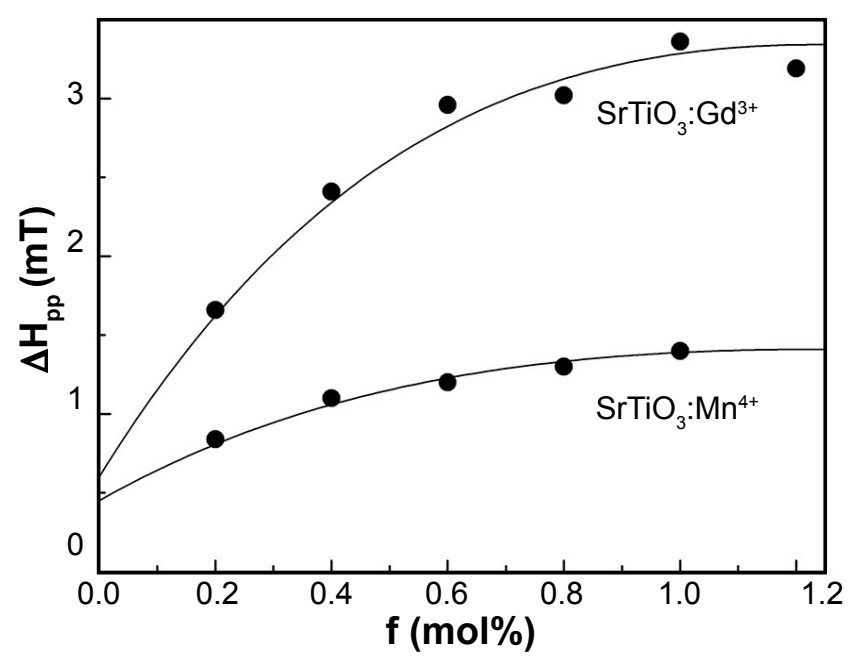

Figure 4: Concentration dependence of the peak-to-peak linewidth, $\Delta \mathrm{H}_{\mathrm{pp}}$, in Gd-doped and Mn-doped $\mathrm{SrTiO}_{3}$. The circles are experimental points; the curves are theoretical: $\Delta \mathrm{H}_{\mathrm{pp}}=0.60+600$.f.(1-f) ${ }^{80}$ for Gd-doped $\mathrm{SrTiO}_{3} \quad[20]$, and $\Delta \mathrm{H}_{\mathrm{pp}}=0.45+210$.f.(1-f) ${ }^{80}$ for Mn-doped $\mathrm{SrTiO}_{3}$ (this study).

[Figura 4: Variação da largura de linha pico a pico, $\Delta H_{p p}$, com a concentraçãoem $\mathrm{SrTiO}_{3}$ dopadocom Gde Mn. Os círculos são pontos experimentais; as curvas são teóricas: $\Delta H_{p p}=0,60+600 . f .(1-f)^{80}$ para $\mathrm{SrTiO}_{3}$ dopado com Gd [18] e $\Delta H_{p p}=0,45+210 . f .(1-f)^{80}$ para $\mathrm{SrTiO}_{3}$ dopado com $\mathrm{Mn}$ (este estudo).]

were incorporated as independent $\mathrm{Mn}^{4+}$ ions in $\mathrm{Ti}^{4+}$ sites and this led to a decrease in the value of c, although this decrease seems to be not sufficient to explain the large difference between the coefficients in $\mathrm{Gd}^{3+}$ and $\mathrm{Mn}^{4+}$ doped $\mathrm{SrTiO}_{3}$.

Table II - Values of $\mathrm{r}_{\mathrm{c}}$ and $\mathrm{z}\left(\mathrm{r}_{\mathrm{c}}\right)$ for $\mathrm{SrTiO}_{3}$. [Tabela II - Valores de $r_{c}$ e $z\left(r_{c}\right)$ para SrTiO ${ }_{3}$.]

\begin{tabular}{ccccccccc}
\hline $\mathrm{n}$ & 1 & 2 & 3 & 4 & 5 & 6 & 7 & 8 \\
\hline $\mathrm{r}_{\mathrm{c}}(\mathrm{nm})$ & 0.00 & 0.39 & 0.55 & 0.68 & 0.78 & 0.87 & 0.96 & 1.11 \\
$\mathrm{z}\left(\mathrm{r}_{\mathrm{c}}\right)$ & 0 & 6 & 18 & 26 & 32 & 56 & 80 & 92 \\
\hline
\end{tabular}




\section{CONCLUSIONS}

The EPR spectra of $\mathrm{Mn}^{4+}$ and $\mathrm{Mn}^{2+}$ were observed in $\mathrm{SrTiO}_{3}$ powders doped with different concentrations of manganese. The measurements showed that Mn ions occupy preferentially $\mathrm{Ti}^{4+}$ sites. It was also found that the EPR peakto-peak linewidth of $\mathrm{Mn}^{4+}$ increased predictably with $\mathrm{Mn}$ concentration and that the range of the exchange interaction between $\mathrm{Mn}^{4+}$ ions was about $0.96 \mathrm{~nm}$. These results may contribute to the study of the magnetic properties of manganese-doped strontium titanate.

\section{ACKNOWLEDGMENTS}

The authors thank CNPq and CAPES for financial support.

\section{REFERENCES}

[1] W.L. Suchanek, M. Yoshimura, J. Am. Ceram. Soc. 81 (1998) 2864.

[2] G.H. Haertling, J. Am. Ceram. Soc. 82 (1999) 797.

[3] V.V. Srdic, R.R. Djenadic, J. Optoelectron. Adv. Mater. 7 (2005) 3005.

[4] F. Xiang, H. Wang, H. Yang, Z.Y. Shen, X. Yao, J. Electroceram. 24 (2010) 20.

[5] Y.T. Qian, K.D. Li, W.S. Wang, J.H. Wang, X.C. Cheng, Y.L. Zhou, J.M. Du, H.J. Chen, B. Zhang, D.J. Kang, J. Nanosci. Nanotechnol. 9 (2019) 5707.

[6] A.G. Sale, S. Kazan, J.I. Gatiiatova, V.F. Valeev, R.I. Khaibullin, F.A. Mikailzade, Mater. Res. Bull. 48 (2013) 2861.

[7] D.M Long, B.Y. Cai, J.N. Baker, P.C. Bowes, T.J.M. Bayer, J.J. Wang, R. Wang, L.Q. Chen, C.A. Randall, D.L.
Irving, E.C. Dickey, J. Am. Ceram. Soc. 102 (2019) 3567.

[8] E.R. Silva, M. Curi, J.G. Furtado, H.C. Ferraz, A.R. Secchi, Ceram. Int. 45 (2019) 9761.

[9] P. Singh, P. Singh, O. Parkash, D. Kumar, J. Mater. Sci. 43 (2008) 989.

[10] C.L. Diao, H. Li, Y. Yang, H. Hao, Z.H. Yao, H.X. Liu, Ceram. Int. 45 (2019) 11784.

[11] R.S. de Biasi, A.A.R. Fernandes, J. Am. Ceram. Soc. 64 (1984) C173.

[12] R.S. de Biasi, A.A.R. Fernandes, M.L.N. Grillo, J. Am. Ceram. Soc. 76 (1993) 223.

[13] R.S. de Biasi, A.A.R. Fernandes, M.L.N. Grillo, J. Am. Ceram. Soc. 79 (1996) 2179.

[14] R.S. de Biasi, M.L.N. Grillo, J. Am. Ceram. Soc. 86 (2003) 195.

[15] R.S. de Biasi, M.L.N. Grillo, J. Am. Ceram. Soc. 91 (2008) 3469.

[16] R.S. de Biasi, M.L.N. Grillo, Ceram. Int. 39 (2013) 2171.

[17] V.V. Laguta, I.V. Kondakova, P. Bykov, M.D. Glinchuk, A. Tkach, P.M. Vilarinho, L. Jastrabik, Phys. Rev. B 76 (2007) 54104.

[18] C. Kittel, E. Abrahams, Phys. Rev. 90 (1953) 238.

[19] R.S. de Biasi, A.A.R. Fernandes, J. Phys. C Solid State Phys. 16 (1983) 5481.

[20] R.S. de Biasi, M.L.N. Grillo, Mater. Chem. Phys. 130 (2011) 409.

[21] A. Zorko, M. Pregelj, H. Luetkens, A.-K. Axelsson, M. Valant, Phys. Rev. B 89 (2014) 94418.

[22] D. Daraselia, D. Japaridze, Z. Jibuti, A. Shengelaya, K.A. Müller, J. Appl. Phys. 121 (2017) 145104.

[23] R.D. Shannon, Acta Cryst. A 32 (1976) 751.

[24] R.S. Biasi, M.L.N. Grillo, Mater. Res. 18 (2015) 288.

(Rec.04/04/2019, Rev.04/06/2019, 01/07/2019, 12/11/2019, Ac. 15/11/2019) 